\title{
Choline Chloride-Based DES as Solvents/Catalysts/Chemical Donors in Pharmaceutical Synthesis
}

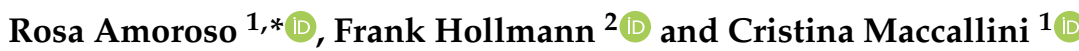 \\ 1 Department of Pharmacy, University of Chieti, Via dei Vestini 31, 66100 Chieti, Italy; \\ cristina.maccallini@unich.it \\ 2 Department of Biotechnology, Delft University of Technology, van der Maasweg 9, \\ 2629 HZ Delft, The Netherlands; f.hollmann@tudelft.nl \\ * Correspondence: ramoroso@unich.it; Tel.: +39-0871-3554686
}

Citation: Amoroso, R.; Hollmann, F.;

Maccallini, C. Choline Chloride-

Based DES as Solvents/Catalysts /

Chemical Donors in Pharmaceutical Synthesis. Molecules 2021, 26, 6286.

https://doi.org/10.3390/

molecules26206286

Academic Editor:

Diego Muñoz-Torrero

Received: 23 September 2021

Accepted: 15 October 2021

Published: 18 October 2021

Publisher's Note: MDPI stays neutral with regard to jurisdictional claims in published maps and institutional affiliations.

Copyright: (C) 2021 by the authors. Licensee MDPI, Basel, Switzerland. This article is an open access article distributed under the terms and conditions of the Creative Commons Attribution (CC BY) license (https:// creativecommons.org/licenses/by/ $4.0 /)$.

\begin{abstract}
DES are mixtures of two or more compounds, able to form liquids upon mixing, with lower freezing points when compared to the individual constituents (eutectic mixtures). This attitude is due to the specific hydrogen-bond interactions network between the components of the mixture. A notable characteristic of DES is the possibility to develop tailor-made mixtures by changing the components ratios or a limited water dilution, for special applications, making them attractive for pharmaceutical purposes. In this review, we focused our attention on application of ChCl-based DES in the synthesis of pharmaceutical compounds. In this context, these eutectic mixtures can be used as solvents, solvents/catalysts, or as chemical donors and we explored some representative examples in recent literature of such applications.
\end{abstract}

Keywords: NADES; choline chloride; pharmaceuticals; solvent; catalyst

\section{Introduction}

Within the framework of green chemistry, also known as sustainable chemistry, solvents play a very strategic role, considering their importance as reaction media and in purification processes. Classical organic solvents often have a large number of intrinsic drawbacks; in fact, they are generally volatile, flammable, and hardly degradable. For human beings, long-term exposure can lead to chronic toxicity, and deleterious effects on respiratory, hematological, and thyroid functioning [1].

In the last decades, a large number of studies have been conducted to replace classical organic solvents with new sustainable ones, with the aim to improve the protection of environmental and human health [2]. This approach comprises the use of different systems, such as the deep eutectic solvents (DES), first described by Abbott et al. as potential alternative solvents to ionic liquids (ILs) [3]. When a DES is composed by natural origin components, it is further defined as a natural deep eutectic solvent (NADES) [4]. DES/NADES are selected mixtures of two or more components, namely hydrogen-bond acceptors (HBA) and hydrogen-bond donors (HBD), which have the capability to form eutectic mixtures with non-ideal behavior, characterized by a greatly depressed melting point relative to their components. The solid-liquid equilibria and eutectic temperatures of DES are the result of a combination of melting points, enthalpies of fusion, and intermolecular attractions. In particular, the negative deviation to thermodynamic ideality arises from the formation of strong bond interactions between the DES precursors [5].

Additionally, the peculiar properties of DES with respect to volatile solvents are the result of an intense network of intermolecular forces, mostly hydrogen bonds between the constituents, that makes these structures unique. Several authors have tried to rationalize the melting point depression, underlining the key role of the hydrogen bond on the system entropy; in DES, the complexation of the HBA anion, through an ionic hydrogen bond by the HBD, generates a delocalization of the negative charge, an increase in the size, and 
a weaker interaction with the cationic counterpart in the HBA. Thus, the involvement of a HBD delocalizes the molecular lattice of HBA, causing a melting point depression, with a direct relationship between the freezing temperature and the network of hydrogen bonds $[6,7]$. Typical DES physicochemical parameters, such as high viscosity and density, can be rationalized by the "hole theory", proposed by Abbot et al. [8]. This phenomenological model assumes that, on melting, an ionic material contains empty spaces (holes) with random sizes and locations, continuously arising by variations in density. In DES, the complexation of the anions results in an increase of size; since the holes are smaller at low temperatures, large-sized ions move with difficulty in these systems. Thus, the involvement of a HBD delocalizes the molecular lattice of HBA, causing, for example, an increase of viscosity.

DES can be divided into various classes, based on the nature of the HBA and HBD used in their preparation: quaternary ammonium salts and anhydrous metal halides (type I), quaternary ammonium salts and hydrated metal halides (type II), ammonium quaternary salts and neutral organic compounds (type III), metal chloride salts and neutral organic compounds (type IV), and mixtures non-ionic species (type V) [9,10]. Within these four DES classes, single components can be combined to form binary or ternary eutectic mixtures.

NADES are a specific subgroup of DES composed of naturally occurring components, such as sugars, organic acids, alcohols, amino acids, urea, choline chloride, and water. This denomination, coined by Choi et al., is not used by all scientists; thus, it is possible to find eutectic mixtures described as DES which fit in the definition of NADES. In biological systems, the NADES could play a role as a third type of medium, an alternative to water and lipids, involved in the biosynthesis, storage, and transport of poorly water-soluble biomolecules, but also in the survival of organisms at prohibitive low-temperature conditions [11]. NADES are particularly attractive because they are characterized by low volatility, a liquid state even in sub-zero temperatures, biodegradability, solute stabilization, stability to air, and easy preparation. Then, it is not surprising that they have found interesting applications in various areas of chemistry, such as in electrochemistry, synthesis, biocatalysis, analytical chemistry, and innovative technologies of extraction [12-15]. One of the main advantages of DES is that their properties can be modulated by changing the component ratios or by water dilution, developing tailor-made mixtures for appropriate applications; in this way, a decrease in viscosity can also be achieved [16].

Many studies consider that DES are nontoxic, based on the fact that most of the components forming DES are natural products. However, the toxicity of the final mixture must be carefully assessed since significant differences from the individual constituents might be observed [17]. Toxicity and biodegradability evaluations can be carried out by different approaches, and this could affect the obtained results. For example, it was reported that the acetylcholine chloride $(\mathrm{AcChCl}) /$ acetamide (1:2) DES toxicity can be due to acidification of the cell's media, due to DES hydrolysis. However, this cytotoxic effect occurred only at high concentrations, higher than $600 \mathrm{mM}$ [18]. Therefore, if on one hand the ecotoxicological profile of DES is not well defined and further evaluations are necessary, on the other they appear as a safer solvent with respect to conventional organic ones [19].

The low toxicity associated with the single components of DES makes these solvents very appropriate for pharmaceutical applications. One of the first applications in this field was the use of DES to increase drug solubility, with the aim to improve the pharmacokinetic aspects like absorption and excretion. This concept was developed up to the definition of the so-called therapeutic deep eutectic solvents (THEDES), in which one component of the eutectic mixture is a drug [20]. Still remaining in the pharmaceutical field, another important aspect of sustainability is the use of appropriate solvents during drug synthesis. Concerning this, some pharmaceutical companies have recently expanded their solvent selection guides with the aim to reduce the use of the most hazardous solvents [21]. DES fit well in this context, in which the researchers try to optimize the conditions of organic synthesis from a green point of view. In particular, the properties of high thermal stability, low vapor pressure, and the possibility of acting both as catalysts and as reaction 
media make these solvents promising candidates for innovative drug syntheses. Thanks to the possibility of tuning their chemical and physical properties, the DES also show high versatility in the efficient creation of complex pharmaceutical scaffolds. One last very important aspect is the low monetary impact of DES, which is an important feature thinking of production on an industrial scale.

A great deal of published methodologies involve one-pot or multicomponent reactions, with a significantly reduced number of solvents needed for intermediate purification [22]. In this context, we focused our attention on published studies in which choline chloride $(\mathrm{ChCl})$-based DES are used as solvents, solvents/catalysts, or chemical donors in the synthesis of pharmaceutical compounds. Here we present a literature summary covering representative examples.

\section{Structure and Properties of Choline Chloride-Based DES}

The most studied DES contain $\mathrm{ChCl}$ (2-hydroxyethyl-trimethylammonium chloride), which is a naturally occurring bifunctional compound containing both a quaternary ammonium salt and alcohol. It is an essential nutrient, commonly grouped with the B-complex vitamins, that plays key roles in methyl group metabolism, carcinogenesis, and lipid transport [23]. In eutectic mixtures, $\mathrm{ChCl}$ functions as $\mathrm{HBA}$ with a variety of $\mathrm{HBD}$, such as urea, alcohols, sugars, hydroxyacids, and aminoacids, due to the simple preparation, nontoxic nature, good biodegradability, and preservation of bioactivities of target compounds [24]. Most interestingly, $\mathrm{ChCl}$-based DES offer the advantage to be modulated in viscosity, $\mathrm{pH}$, and polarity for their applications in health-related areas, such as pharmaceuticals, foods, and cosmetics [25]. The main limitations of these solvents are the significantly high viscosities and densities in comparison with water and common organic solvents, which can reduce mass and energy transfer during chemical reactions; water or glycerol addition and mild heating contribute to the disruption the hydrogen-bond network and weaken the intermolecular forces, although keeping the solvent supramolecular structure [26].

The structure of $\mathrm{ChCl}$-based DES have been explored by several experimental techniques such as nuclear magnetic resonance (NMR), crystallography, mass spectrometry (MS), and infrared spectroscopy (FT-IR) [27]. Recently, computational studies have been conducted, allowing further knowledge of the supramolecular structure of these eutectic mixtures, showing that the hydrogen bonds or even the Van der Waals interactions interfere with the capacity of the initial compounds to crystallize [28]. In particular, density functional theory (DFT) demonstrated that, in ChCl-based DES, the electronegative anion chloride is capable to provide more binding sites to form hydrogen bonds, and a competitive activity was observed between various HBD and choline cation [29]. In this scenario, the formation of hydrogen bonds and the consequent delocalization of charges, in addition to designing the three-dimensional network, significantly decreases the melting points of the different eutectic mixtures.

ChCl-based eutectic mixtures could be classified into groups, based on HBD type: alcohol- and sugar-based, acid-based, amide-based, water-based, and ternary mixtures. Most of these mixtures are liquid at room temperature and can thus be used as solvents in many applications.

In alcohol- and sugar-based eutectics, the HBD are glycols, glycerol, and sugars. These solvents exhibit a neutral $\mathrm{pH}$ in the mixture, and this may be very useful for expanding applications [30]. A detailed hydrogen bond analysis performed by Perkins et al. on $\mathrm{ChCl}$ :ethylen glycol (ethaline) and $\mathrm{ChCl}$ :glycerol (glyceline) suggested that the predominant intermolecular hydrogen bond is formed by anion chloride-hydroxyl group of HBD, while the cation choline interactions seem to represent the smallest contribution to the extensive network of intermolecular forces [31]. Recently, Biernacki et al. reported an experimental and theoretical study of ChCl-based NADES with sorbitol and xylitol. In these solvents, the oversaturation of the HBD groups results in more extensive self-interaction compared to NADESs with ethylene glycol and glycerol, with higher viscosities and densities [32]. 
The acid-based mixtures consist of natural carboxylic acids, with characteristics similar to ionic liquids. Obviously, the carboxylic functions are hydrogen donors, and the freezing points are lower than $50{ }^{\circ} \mathrm{C}$. One of the advantages of this type of solvent is the possibility to use them as acid catalysts; furthermore, varying the $\mathrm{pH}$ of the eutectic liquid, it is possible to design a solvent with specific properties and different catalytic activity [33]. Regarding the supramolecular structure, an instructive example is that of "maline" (ChCl:malonic acid), a NADES that exhibits an extensive amount of anion chloride-HBD and anion chloride-choline interactions, which drastically increase the bonding network and decrease the mobility of molecules within the mixture [31].

Among the amide-based, the most studied DES is a 1:2 mixture of $\mathrm{ChCl}$ and urea, named "reline", firstly proposed by Abbott et al. in 2003 [3]. The melting point of the dry eutectic is $12{ }^{\circ} \mathrm{C}$, substantially lower than the constituent pure components $\left(\mathrm{ChCl} \mathrm{mp}=302{ }^{\circ} \mathrm{C}\right.$, urea $\left.\mathrm{mp}=133{ }^{\circ} \mathrm{C}\right)$. The properties of reline have been extensively studied and rationalized, providing an explanation for the optimal ratio of 1:2 between $\mathrm{ChCl}$ and urea [34]. In a mixture of $\mathrm{ChCl}$ and urea, there is the possibility of an "alphabet soup" of hydrogen bonds, ( $\mathrm{ChCl}$ ion pairs, urea, and chloride, choline, and urea, and urea-urea), in contrast with traditional molecular solvents which have a homogeneous hydrogen bond network. This peculiarity could be expected to increase the entropy of the system, with the decrease of the melting point [35]. The supramolecular structure of ChCl:urea 1:2 was described as a radially layered "sandwich", where choline and urea work synergistically to bond with the chloride anion, allowing for the best distribution of charge between each component in a stoichiometrically determined fashion [36].

Aquoline is a eutectic solvent solely composed of $\mathrm{ChCl}$ and water in a 1:3.33 molar ratio, with a much lower viscosity than other common NADES. This mixture is prepared by mixing water and $\mathrm{ChCl}$ hydrate, and it is presently attracting considerable attention in electrochemistry [37]. A recent study by Triolo et al. identified for this "uncoventional $D E S^{\prime \prime}$ a complex structural scenario based on coordination of cation choline with water and anion chloride, dispersed in the bulk phase in which long chains of water are present, generated by interactions between water-water and water-chloride [38].

The addition of a third HBD to a DES causes the formation of a ternary mixture. Usually, the third component is water, and, although a physiological amount of water strengthens the hydrogen-bond network within the DES, amounts higher than $10 \%$ can weaken the interactions between each component of the mixture, generating variations of properties such as density and viscosity. In addition to water, which is the most frequent additive, glycerol, methanol, ethanol, and 2-propanol were also used [39]. The effects of these components on the supramolecular structure of DES were studied and furnished information especially for dedicated applications, where the structural features play a crucial role [40].

\section{Choline-Based DES as Solvents/Catalysts in Pharmaceutical Synthesis}

\subsection{Choline-Based DES as Solvents}

As reported above, in the last years, DES have been utilized in organic synthesis as green media thanks to the high potential to replace the classical solvents. In fact, since the DES are characterized by a network of hydrogen bonds, they have the possibility to dissolve solutes that can form hydrogen bonds and stabilize transition states. Furthermore, during the purification procedures, the addition of water to a DES (very soluble in water) causes the precipitation of organic products, facilitating the workup and avoiding the use of solvents for the extraction. From the point of view of ecological footprint, most DES come from renewable sources and, thanks to their low vapor pressure, biodegradability, and almost non-existent toxicity, they are considered green solvents. In this section, some representative examples of building block synthesis in ChCl-based DES will be examined, with applications in medicinal chemistry.

The thiazolidin-4-one system is a privileged heterocycle present in many synthetic analogs with a wide range of pharmacological activities [41]. In particular, the 2-imino 
thiazolidin-4-one pharmacofore has been reported to exhibit anticancer properties that can be associated with the affinity for some biotargets [42]. Among the several synthetic routes available for the synthesis of the multifunctionalized 2-iminothiazolidin-4-ones, Mobinikhaledi and Amiri modified the classical pathway based on condensation between thioureas with chloroacetyl chloride, by introducing a one-pot three-component reaction in NADES, obtaining a variety of 5-arylidene-2-imino-4-thiazolidinones [43]. As shown in Scheme 1, they investigated the reaction of thioureas, chloroacetyl chloride, and aromatic aldehydes in $\mathrm{ChCl} /$ urea. The best results were obtained with condensation of $N, N^{\prime}$-diphenylthiourea, chloroacetyl chloride, and benzaldehyde to give 5-benzylidene-3phenyl-2(phenylimino) thiazolidin-4-one in 94\% yield.<smiles>CC1C(=O)N([Al])C(=N[Al])SC1CBr</smiles>

Scheme 1. Condition reactions: $\mathrm{ChCl} /$ urea $(12), 30 \mathrm{~min}, 80^{\circ} \mathrm{C}(\mathrm{Ar}=\operatorname{aryl})$.

The bis(indolyl)methanes (BIM) are indole derivatives with a broad spectrum of biological and pharmacological activities, present in various natural products and possessing important biological activity [44]. In particular, some BIM from cruciferous plants inhibit breast cancer cell proliferation by activation of multiple pathways, suggesting a potential role in the clinical treatment of ER-negative breast cancer [45]. The methods of BIM synthesis involve both one step as well as multistep strategies, based on the condensation of indoles and carbonyl compounds, using protic acids and Lewis acids as catalysts [46]. Recently, Grosso et al. reported the use of ChCl-based DES as green solvents to carry out a bis-hetero-Diels-Alder addition of nitroso- and azoalkenes with indoles [47]. The obtained BIM furnished, after hydrolysis, the corresponding carbonyl-BIM. Among the numerous reactions proposed, the best yields $(50-80 \%)$ were obtained in the synthesis of hydrazonomethyl-BIM in $\mathrm{H}_{2} \mathrm{O} /[\mathrm{ChCl} /$ glycerol (2:1)] (3:1) starting from alkylhydrazones (Scheme 2).<smiles>[R]N/N=C(/C)C(Cl)Cl</smiles><smiles>[CH2+]CC</smiles><smiles>[R]c1ccc2c(ccn2[R1])c1</smiles><smiles>CCCCCCC</smiles><smiles>[R2]c1ccc2c(c1)c(C(/C(C)=N\NN)c1cn([R1])c3ccc([R])cc13)cn2[R1]</smiles>

$$
\mathrm{R}=\mathrm{Ts} \text {, Boc } \quad \mathrm{R}_{1}=\mathrm{H}, \mathrm{Me} \quad \mathrm{R}_{2}=\mathrm{H}, \mathrm{Me}, \mathrm{OH}
$$

Scheme 2. Condition reactions: $\mathrm{H}_{2} \mathrm{O} /\left[\mathrm{ChCl} /\right.$ glycerol (2:1)] (3:1), $\mathrm{Na}_{2} \mathrm{CO}_{3}, 10-60$ min, r.t.

Chiral 1,3-dicarbonyl compounds bearing an $\alpha$-amine moiety represent an important structural motif present in natural compounds, most of them having biological and pharmaceutical activity [48]. Among the methods to gain access to this motif, significant developments have been reached in the asymmetric organocatalyzed amination of prochiral carbonyl compounds employing diazocarboxylates as nitrogen source [49]. Nigues et al. have improved the sustainability of this reaction by using $\mathrm{ChCl} /$ glycerol and $\mathrm{ChCl}$ /urea as the solvents and 2-aminobenzimidazole derivatives as catalysts [50]. As depicted in Scheme 3, the reaction of ethyl 2-oxocyclopentane-1-carboxylate with di-tbutyl-azodicarboxylate (DBAB) with a chiral 2-aminobenzimidazole derivative as catalyst under the optimized conditions gave the product of amination in excellent yield (94\%) and good enantioselectivity ( $73 \%$ e.e.). 


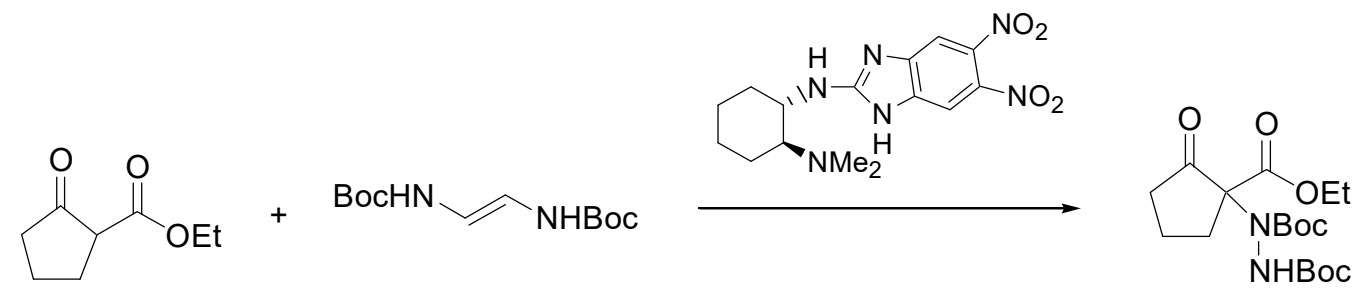

Scheme 3. Condition reactions: $\mathrm{ChCl} /$ glycerol $(1: 2), 1 \mathrm{~h}, 25^{\circ} \mathrm{C}$.

Propargylamines are alkyne coupled amine compounds used as skeletal structures in heterocyclic chemistry and drug design [51]. For example, rasagiline is a monoamine oxidase (MAO)-B inhibitor with neuroprotective and antiapoptotic effects, used in Parkinson's disease and other neurodegenerative conditions [52]. Because of its versatility and wide use in organic synthesis, a number of methodologies have been developed for propargylamine derivatives, in particular three-component reactions of aldehydes, amines, and alkynes [53]. This method has been recently improved by substituting the classical solvents with environmentally friendly $\mathrm{ChCl} /$ urea [54]. First, the reaction between benzaldehyde, morpholine, and phenylacetylene in the presence of $\mathrm{CuCl}(5 \mathrm{~mol} \%)$ as a catalyst was selected as a model to set the best conditions (solvent, catalyst amount, temperature, and time). Then, various aldehydes were used, and the best results were obtained with aromatic aldehydes with electron donor groups (38-90\%) (Scheme 4).

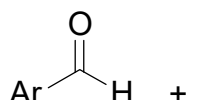<smiles>C1COCC[NH2+]1</smiles><smiles>C#Cc1ccccc1</smiles>
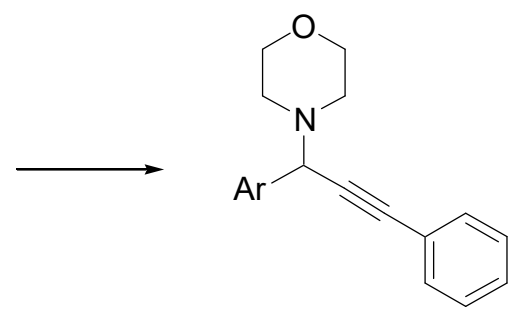

Scheme 4. Condition reactions: $\mathrm{ChCl} /$ urea $(1: 2), \mathrm{CuCl}(5 \mathrm{~mol} \%), 15 \mathrm{~h}, 60^{\circ} \mathrm{C}(\mathrm{Ar}=\operatorname{aryl})$.

Benzoxazines are compounds where an oxazine ring is condensed to a benzene ring, used in polymers, resins, and in the construction of interesting drug candidates as antilipidemics [55]. In this field, interesting compounds are the cardanol-derived benzoxazines. Cardanol is a natural oil with a phenolic structure, extracted from cashew or from Gingko biloba, extensively studied for its possible applications in industry and in pharmaceutical chemistry [56]. Behalo et al. developed a green Mannich-like condensation of a cardanol with its unsaturated derivative, aniline, and formaldehyde, in $\mathrm{ChCl} /$ urea as DES with good yields (81-88\%) (Scheme 5). They also demonstrated the use of cardanol-based benzoxazines as scaffolds for the preparation of vesicular nanosystems [57].<smiles>[R]c1ccc2c(c1)OCN(c1ccccc1)C2</smiles>

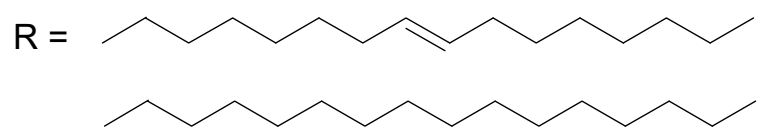

or (cardanol)

Scheme 5. Condition reactions: $\mathrm{ChCl} /$ urea $(1: 2), 4 \mathrm{~h}, 70^{\circ} \mathrm{C}$. 
Nicotinamide is an important naturally occurring heterocycle, which belongs to group $B$ vitamins. Quaternary derivatives of nicotinamide have attracted much attention because of their antimicrobial, fungicidal, and cytotoxic properties [58]. The most common strategy for quaternization of nicotinamide is the nucleophilic substitution between pyridine and substituted 2-bromoacetophenones, called the Menschutkin reaction [59]. Busic et al. investigated the use of three ChCl-based DES in the quaternization of nicotinamide with 2-bromoacetophenones, performed by a conventional approach, microwaves (MW), and ultrasonic irradiation (blue). The highest yields were obtained by MW, and independently from the adopted solvent (Scheme 6) [60].<smiles>[R]c1ccc(C(=O)CBr)cc1</smiles><smiles>[R]c1ccc(C(=O)C[n+]2cccc(C(N)=O)c2)cc1</smiles>

Scheme 6. Condition reactions: $\mathrm{ChCl} /$ urea, ossalic acid, or levulinic acid, $\mathrm{MW}, 20 \mathrm{~min}, 80^{\circ} \mathrm{C}$.

\subsection{Choline-Based DES as Solvents/Catalysts}

As described above, DES had great potential as a green alternative to classical organic solvents; in addition, in the last years, they have emerged as catalysts for various organic reactions, because they can be applied both as reaction media and as catalytic active species, providing homogeneous solutions. Although there are numerous examples of the catalytic effect of DES, this role has not been fully defined yet. To date, some mechanisms of catalysis have been proposed, mostly based on the formation of hydrogen bonds between the reactants and DES, thus facilitating the breaking of the chemical bonds involved in the reaction [33]. In this section, some representative examples of reactions carried out in $\mathrm{ChCl}$ based DES working both as solvents and catalysts will be described. In reacting substrates, the function involved is always a carbonyl group, which is activated by DES thanks to its ability to establish strong hydrogen bonds, thus facilitating the subsequent electrophilic attack in reactions such as Michael additions, transesterifications, and condensations (Figure 1).

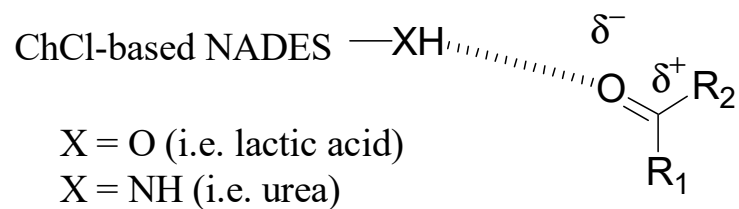

Figure 1. Activation of a carbonyl group by a ChCl-based DES/NADES as catalyst.

Aurones, (Z)-2-benzylidenebenzofuran-3(2H)-ones, are a subclass of flavonoids that provide the golden-yellow color in many ornamental flowers. They exhibit a broad spectrum of activities including anticancer, antioxidant, antiparasitic, and antibacterial properties [61]. The simplest chemical synthesis of aurones is based on the condensation of a coumaranone with an aldehyde, under acidic, or basic conditions. Hawkins and Handy discovered a neutral condition for this condensation, based on the use of $\mathrm{ChCl} /$ urea, although with not excellent yields (max 73\%) [62]. The reaction proceeds simply and cleanly by mixing the reactants in DES, and the desired aurones were recovered by extractive workup (Scheme 7). 


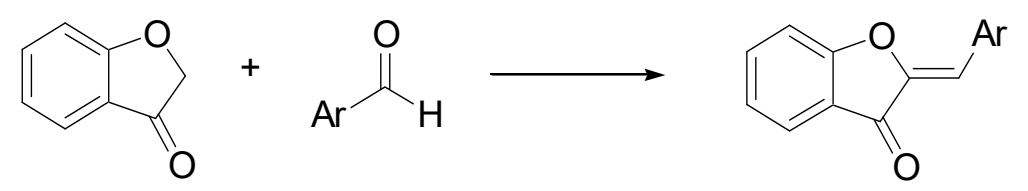

Scheme 7. Condition reactions: $\mathrm{ChCl} /$ urea $(1: 2), 12-48 \mathrm{~h}, 80^{\circ} \mathrm{C}(\mathrm{Ar}=\operatorname{aryl})$.

Novobiocin is a naturally occurring compound containing the aminocoumarin scaffold, with hopeful anticancer activity. Besides, other dihydrocoumarin and aminocoumarin derivatives possess significant bioactivities such as cytotoxic, anti-inflammatory, and antibiotic [63]. Despite the role as therapeutic agents, the available synthetic methods require toxic solvents or metal catalysts, with adverse effects on the environment. A new tandem approach to prepare the 3-aminohexahydroxcoumarins directly from aryl aldehydes, ippuric acid, acetic anhydride, and 1,3-dicarbonyl compounds, with $\mathrm{ChCl}$ /urea as a biorenewable solvent was developed by Zamani and Khosropour [64]. After preliminary studies in the bath, the reactions were conducted in a continuous micro-flow reactor, including two tubing glass (Q1 for aryl aldehydes, hippuric acid, and acetic anhydride, and Q2 for 1,3-dicarbonyl compounds) giving faster and quicker results. In Q1 an azalactone intermediate is formed, and then in Q2 the Michael addition of 1,3-dicarbonyl compounds gives rise to the target products (Scheme 8).

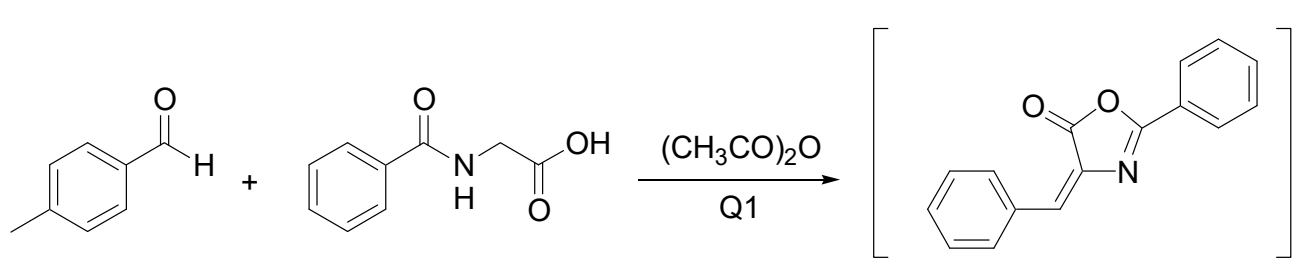<smiles>[R]C1CC(=O)CC([R])C1</smiles><smiles>[R2]C1([R2])CC(=O)C2=C(C1)OC(=O)C(NC(=O)c1ccccc1)C2c1ccccc1</smiles>
$\mathrm{R}_{1}=\mathrm{R}_{2}=\mathrm{H}$ or $\mathrm{CH}_{3}$

Scheme 8. Optimized condition reactions: $\mathrm{ChCl} /$ urea (1:2), $120^{\circ} \mathrm{C}, 40 \mathrm{~min}(\mathrm{Q} 1)$ and $10 \mathrm{~min}(\mathrm{Q} 2)$.

The cyclopentenone moiety is a fundamental structural motif present in molecules such as prostaglandins, clavulones, and cephalotaxine esters, with significant anticancer activity [65]. Most of the reported synthetic strategies for the preparation of cyclopentenone require expensive catalysts, toxic solvents, and proceed with low yields. Therefore, there is an ongoing interest to develop new methodologies; in particular, erbium (III) chloride has found a good catalyst acting in green solvents, such as ethyl lactate [66]. Recently, Di Gioia et al. developed a simple and rapid method for the conversion of furfural into bifunctionalized cyclopentenones under green conditions by using the $\mathrm{ChCl}$ :urea, without any product purification [67]. They observed that reaction of furfural with secondary amines furnished, after $5 \mathrm{~min}$, the bifuntionalized cyclopentenone $\mathbf{A}$, that was totally converted to the structural isomer $\mathbf{B}$ after $4 \mathrm{~h}$. These two conditions were applied for the synthesis of a series of derivatives, as shown in Scheme 9. 


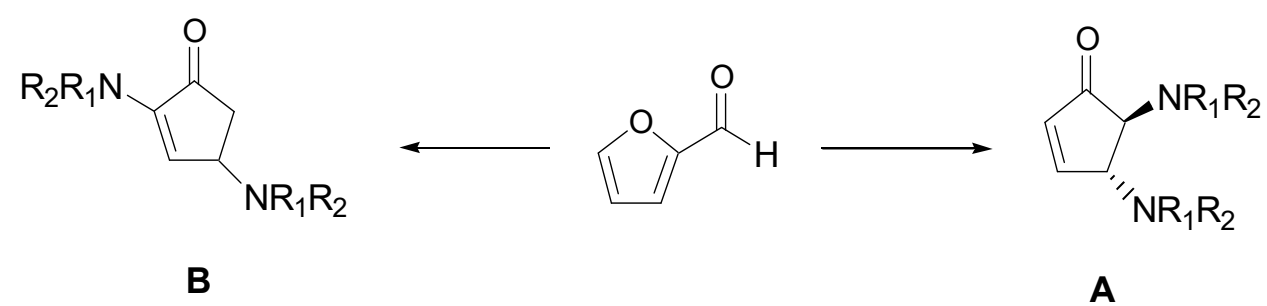

Scheme 9. Optimized reaction conditions: $\mathrm{ChCl} /$ urea $(1: 2), 60^{\circ} \mathrm{C}, 5 \mathrm{~min}(\mathrm{~A})$ and $4 \mathrm{~h}(\mathbf{B})$.

The merger of pyrazolo[3,4-b]pyridine and spirooxindole backbones into a hybrid structure (pyrazolo[3,4-b]pyridine spirooxindole) may result in interesting compounds with potential medicinal applications, since both scaffolds have remarkable pharmacological properties [68]. Of note is the anti-breast-cancer activity of some of these hybrid derivatives [69]. Zangh et al. proposed a sustainable protocol for the synthesis of pyrazolo[3,4-b]pyridines spirooxindoles with a variety of substituents through a one-pot three-component assembly between 1,3-aromatic-1H-pyrazol-5-amines, substituted isatins, and enolizable 1,3 dicarbonyl compounds. Excellent yields (82-95\%) were obtained under microwave (MW) irradiation in ChCl:lactic acid as NADES (Scheme 10) [70].

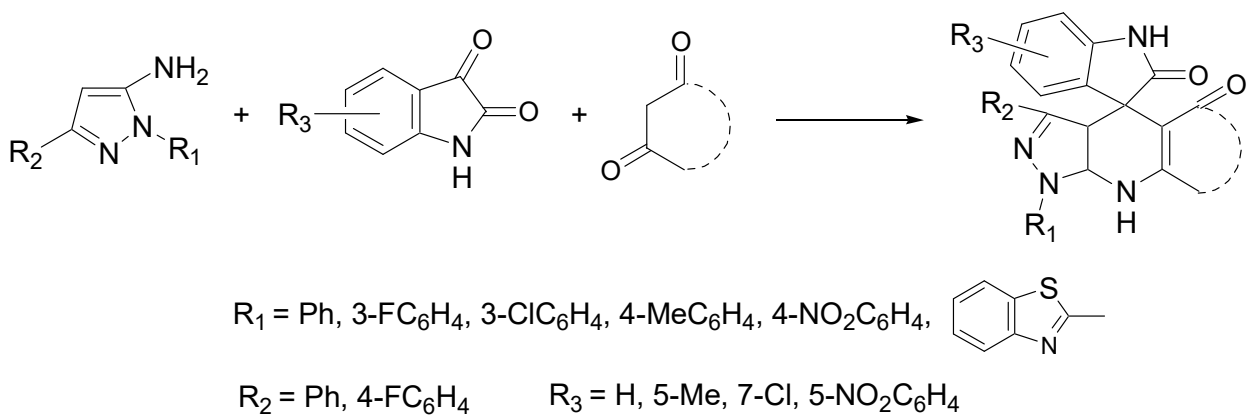

Scheme 10. Reaction conditions: $\mathrm{ChCl} /$ lactic acid (1:2), $\mathrm{MW}, 60^{\circ} \mathrm{C}, 15-30 \mathrm{~min}$.

Pyrazolylphosphonates are biologically interesting compounds containing phosphonate and pyrazole. They have received considerable attention due to their remarkable bioactivity profiles, with promising antioxidant and anticancer activity [71]. This interest has prompted the development of various synthetic approaches, including one-pot multicomponent reactions. Of interest is the condensation of pyrazolones with aldehydes and trialkyl phosphites, based on the in situ formation of benzylidene pyrazolone and subsequent reaction with a phosphorus nucleophile. Kalla and Kim have used as a catalyst for this one-pot synthesis a ChCl-urea mixture, with a series of advantages such as bio-friendly profile, mild conditions at r.t., and the avoidance of chromatographic purification [72]. The authors first developed a model reaction between 5-methylpyrazolone, benzaldehyde, and triethyl phosphite in mild conditions (Scheme 11). Then, the scope reaction was investigated using various aromatic aldehydes, pyrazolones, and trialkyl phosphites, allowing us to assess a clear improvement in product yields (90-96\%) when using DES with respect to the other catalysts previously reported. 
<smiles>CCOP(OCC)OCC</smiles>

Scheme 11. Condition reactions: $\mathrm{ChCl} /$ urea $(1: 2), 25^{\circ} \mathrm{C}, 30 \mathrm{~min}$.

From a synthetic chemistry point of view, the above illustrated 2-imino-4-thiazolidinones are very interesting scaffolds, due to the presence of electrophilic centers and activated exocyclic double bonds, and therefore they can behave like dipolarophiles in 1,3-dipolar cycloaddition reactions. In this context, Singh et al. have used 2-iminothiazolidin-4ones as a core system for the construction of hybrids with spiro-oxindole-pyrrolidines as novel druglike molecules [73]. The preparation of hybrids was carried out with excellent yields (50-92\%) and high regio- and stereo-selectivity by means of the multicomponent 1,3-dipolar cycloaddition of (2Z)-methyl-2-[(Z)-4-oxo-3-aryl-2-(arylimino) thiazolidin-5ylidene] acetate as dipolarophile with substituted isatins and sarcosine, using $\mathrm{ChCl} /$ urea as the green solvent (Scheme 12).<smiles>O=C(O)OC(=O)/C=C1\S/C(=N\Br)N(Br)C1=O</smiles><smiles>[X]c1ccc2c(c1)NC(=O)C2=O</smiles><smiles>CNCC(=O)O</smiles><smiles>[X]c1ccc2c(c1)NC(=O)C21SC(=NBr)N(Br)C1=O</smiles>

$\mathrm{Ar}=\mathrm{C}_{6} \mathrm{H}_{5}, 4-\mathrm{CH}_{3} \mathrm{C}_{6} \mathrm{H}_{5}, 4-\mathrm{BrC}_{6} \mathrm{H}_{5}, 4-\mathrm{F}-\mathrm{C}_{6} \mathrm{H}_{5}, 4-\mathrm{ClC}_{6} \mathrm{H}_{5}$ $\mathrm{X}=\mathrm{H}, 5-\mathrm{CH}_{3}, 5-\mathrm{Cl}, 5-\mathrm{Br}, 5-\mathrm{F}, 5,7-\mathrm{diCH}_{3}$

Scheme 12. Condition reactions: $\mathrm{ChCl} /$ urea $(1: 2), 40-100{ }^{\circ} \mathrm{C}, 2-5 \mathrm{~h}$.

\subsection{Choline-Based DES as Chemical Donors}

In the last years, biocompatible materials for development of drug delivery systems have been synthesized by using NADES as sustainable reaction media [74]. An interesting study conducted by Pradeepkumar et al. described the preparation of a $\varepsilon$-caprolactonecitric acid micellar nanocarrier for controlled release of camptothecin [75]. In this procedure, the NADES acted both as a solvent and as a citric acid donor for the functionalization of caprolactone (Scheme 13). The structure of encapsulated micelles was analyzed by FT-IR and UV spectrometry, and biological studies were performed, showing a controlled release of camptothecin and time-dependent apoptosis. These results suggest that these micellar nanocarriers could represent a potent system for cancer therapy.
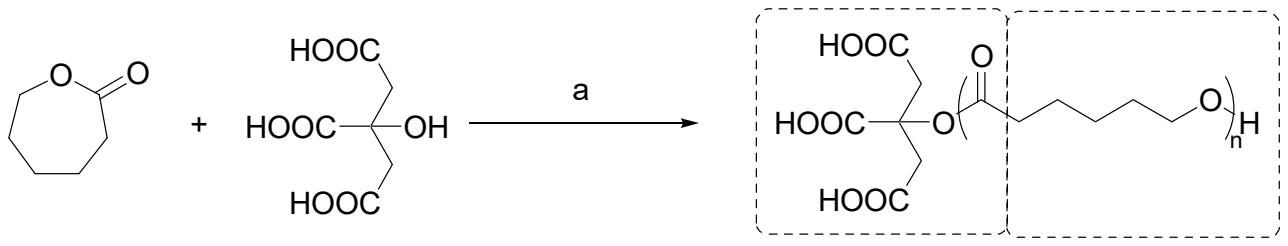

Hydrophilic Hydrophobic

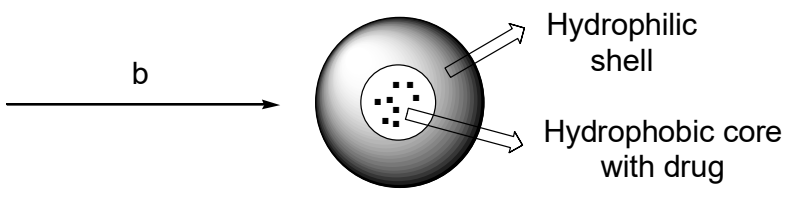

Scheme 13. Condition reactions: (a) $\mathrm{ChCl} /$ citric acid (1:2), $120^{\circ} \mathrm{C}, 24 \mathrm{~h}$; (b) self-assembly, campthotecin. 
Pyrrole is a five membered aromatic heterocycle present in complex macromolecules including porphyrins of heme and chlorophyll and in natural products. Pyrrole derivatives can serve as promising drug candidates with antimicrobial, antiviral, antimalarial, antitubercular, anti-inflammatory, and enzyme inhibiting activities [76]. Hu et al. reported the condensation reaction between tricarbonyl compounds and ammonia generated in situ from the eutectic mixture of $\mathrm{ChCl} /$ urea [77]. Triketones were completely transformed into pyrrole products with high yields at an optimum temperature of $100^{\circ} \mathrm{C}$, and the urea present in the DES was transferred to the final product of the reaction following its thermal decomposition (Scheme 14).

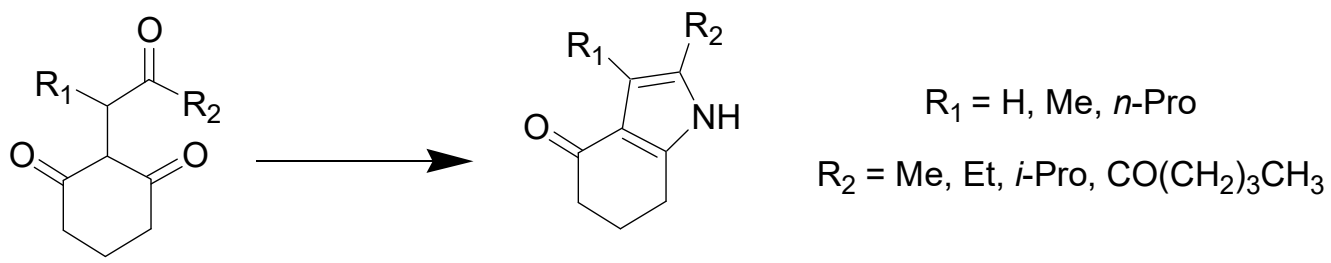

Scheme 14. Condition reactions: $\mathrm{ChCl} /$ urea $(1: 2), 100{ }^{\circ} \mathrm{C}, 8 \mathrm{~h}$.

Caffeic acid is a natural hydroxycinnamic acid phenolic derivative (3,4-dihydroxycinnamic acid), with antioxidant, anti-inflammatory, antimicrobial, and antineoplastic activities [78] However, its unsatisfactory solubilities in both hydrophobic and hydrophilic systems limit its application in chemical industries. Considering that caffeoyl lipophilic alkyl esters show superior biological and pharmacological properties with respect to their phenolic acid counterparts, much research has focused on their preparation in chemical, biochemical, or enzymatic ways [79]. In this field, Wang et al. recently described a novel method for octodecyl caffeate production by using a NADES consisting of $\mathrm{ChCl}$ and caffeic acid as the caffeoyl donor, with cation-exchange resins as green catalysts and fatty alcohols $(\mathrm{ROH})$ as caffeoyl acceptors (yield 91\%) (Scheme 15) [80]. The proposed esterification mechanism involves the $\mathrm{H}^{+}$released from the cation-exchange resin, that attacks the carboxyl carbon of caffeic acid to form a carbocation. Then, the $\mathrm{OH}$ of stearyl alcohol reacts with the carbocation, giving a tetrahedral intermediate, that release $\mathrm{H}_{2} \mathrm{O}$ and $\mathrm{H}^{+}$to form octodecyl caffeate.<smiles>O=C(O)/C=C/c1ccc(O)c(O)c1</smiles>

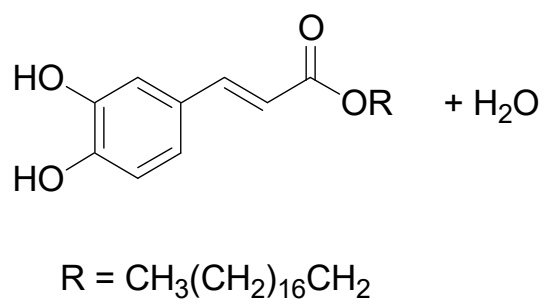

Scheme 15. Optimized condition reactions: $\mathrm{ChCl} /$ caffeic acid, cation-exchange resin A-35 load 5\%, $85^{\circ} \mathrm{C}, 24 \mathrm{~h}$.

\section{Conclusions}

In the last decades, scientific interest in the development of synthetic strategies involving green solvents has been strongly raised, sustained by the economic pressure to maximize process yields, and reduce production costs. This is particularly true in the pharmaceutical field, given the high value of the produced materials. In the present review, recent applications of ChCl-based DES as performing solvents in the synthesis of bioactive compounds were discussed. Most of the reported methodologies involve one-pot or multicomponent reactions; this kind of approach significantly reduced the amounts of solvents needed for intermediate purification. Our attention has focused on reactions in which $\mathrm{ChCl}$-based DES are used as solvents, solvents/catalysts, or chemical donors. From our discussion, it emerged that the use of DES promoted the examined reactions from the point 
of view of yields, reaction times, and purification of the products. Therefore, $\mathrm{ChCl}$-based DES can be suggested as valuable media in the synthesis of pharmaceuticals.

Author Contributions: C.M. coordinated the literature survey and manuscript writing. R.A. contributed to searching and collecting the relevant literature and writing the body of the article. F.H. gave an expert opinion during the compilation and correction of the manuscript. All authors have read and agreed to the published version of the manuscript.

Funding: This research was funded by the University "G. d'Annunzio" of Chieti local grants.

Institutional Review Board Statement: Not applicable.

Informed Consent Statement: Not applicable.

Data Availability Statement: No data are reported.

Conflicts of Interest: The authors declare no conflict of interest.

\section{References}

1. Joshi, D.R.; Adhikari, N. An overview on common organic solvents and their toxicity. J. Pharm. Res. Int. 2019, 28, 1-18. [CrossRef]

2. Clarke, C.J.; Tu, W.-C.; Levers, O.; Bröhl, A.; Hallett, J.P. Green and sustainable solvents in chemical processes. Chem. Rev. 2018, 118, 747-800. [CrossRef] [PubMed]

3. Abbott, A.P.; Capper, G.; Davies, D.L.; Rasheed, R.K.; Tambyrajah, V. Novel solvent properties of choline chloride/urea mixtures. Chem. Commun. 2003, 1, 70-71. [CrossRef] [PubMed]

4. Choi, Y.H.; van Spronsen, J.; Dai, Y.T.; Verberne, M.; Hollmann, F.; Arends, I.W.C.E.; Witkamp, G.J.; Verpoorte, R. Are natural deep eutectic solvents the missing link in understanding cellular metabolism and physiology? Plant Physiol. 2011, 156, $1701-1705$. [CrossRef] [PubMed]

5. Kollau, L.J.B.M.; Vis, M.; van den Bruinhorst, A.; Esteves, A.C.C.; Tuinier, R. Quantification of the liquid window of deep eutectic solvents. Chem. Commun. 2018, 54, 13351-13354. [CrossRef] [PubMed]

6. Garcia, G.; Atilhan, M.; Aparicio, S. An approach for the rationalization of melting temperature for deep eutectic solvents from DFT. Chem. Phys. Lett. 2015, 634, 151-155. [CrossRef]

7. D'Agostino, C.; Harris, R.C.; Abbott, A.P.; Gladden, L.F.; Mantle, M.D. Molecular motion and ion diffusion in choline chloride based deep eutectic solvents studied by $1 \mathrm{H}$ pulsed field gradient NMR spectroscopy. Phys. Chem. Chem. Phys. 2011, 13, 21383-21391. [CrossRef]

8. Abbott, A.P.; Capper, G.; Gray, S. Design of improved Deep Eutectic Solvents using hole theory. ChemPhysChem 2006, 7, 803-806. [CrossRef]

9. Smith, E.L.; Abbott, A.P.; Ryder, K.S. Deep eutectic solvents (DESs) and their applications. Chem. Rev. 2014, 114, 11060-11082. [CrossRef]

10. Abranches, D.O.; Martins, M.A.R.; Silva, L.P.; Schaeffer, N.; Pinho, S.P.; Coutinho, J.A.P. Phenolic hydrogen bond donors in the formation of non-ionic deep eutectic solvents: The quest for type V DES. Chem. Commun. 2019, 55, 10253-10256. [CrossRef]

11. Dai, Y.; Witkamp, G.-J.; Verpoorte, R.; Choi, Y.H. Natural deep eutectic solvents as a new extraction media for phenolic metabolites in Carthamus tinctorius L. Anal. Chem. 2013, 85, 6272-6278. [CrossRef] [PubMed]

12. Paiva, A.; Craveiro, R.; Aroso, I.; Martins, M.; Reis, R.L.; Duarte, A.R.C. Natural Deep Eutectic Solvents - Solvents for the 21st century. ACS Sustain. Chem. Eng. 2014, 2, 1063-1071. [CrossRef]

13. Liu, Y.; Friesen, J.B.; McAlpine, J.B.; Lankin, D.C.; Chen, S.-N.; Pauli, G.F. Natural Deep Eutectic Solvents: Properties, applications, and perspectives. J. Nat. Prod. 2018, 81, 679-690. [CrossRef] [PubMed]

14. Espino, M.; de los Ángeles Fernández, M.; Gomez, F.J.V.; Silva, M.F. Natural designer solvents for greening analytical chemistry. Trends Analyt. Chem. 2016, 76, 126-136. [CrossRef]

15. Gullón, P.; Gullón, B.; Romaní, A.; Rocchetti, G.; Lorenzo, J.M. Smart advanced solvents for bioactive compounds recovery from agri-food by-products: A review. Trends Food Sci. Technol. 2020, 101, 182-197. [CrossRef]

16. Kovacs, A.; Neyts, E.C.; Cornet, I.; Wijnants, M.; Billen, P. Modeling the physicochemical properties of Natural Deep Eutectic Solvents. ChemSusChem 2020, 13, 3789-3804. [CrossRef] [PubMed]

17. de Morais, P.; Gonçalves, F.; Coutinho, J.A.P.; Ventura, S.P.M. Ecotoxicity of cholinium-based Deep Eutectic Solvents. ACS Sustain. Chem. Eng. 2015, 3, 3398-3404. [CrossRef]

18. Torregrosa-Crespo, J.; Marset, X.; Guillena, G.; Ramón, D.J.; Martínez-Espinosa, R.M. New guidelines for testing “Deep eutectic solvents" toxicity and their effects on the environment and living beings. Sci. Total Environ. 2020, 704, 135382. [CrossRef] [PubMed]

19. Alonso, D.A.; Baeza, A.; Chinchilla, R.; Guillena, G.; Pastor, I.M.; Ramón, D.J. Deep Eutectic Solvents: The organic reaction medium of the century. Eur. J. Org. Chem. 2016, 4, 612-632. [CrossRef]

20. Álvarez, M.S.; Zhang, Y. Sketching neoteric solvents for boosting drugs bioavailability. J. Control. Release 2019, 311-312, 225-232. [CrossRef] 
21. Byrne, F.P.; Jin, S.; Paggiola, G.; Petchey, T.H.M.; Clark, J.H.; Farmer, T.J.; Hunt, A.J.; McElroy, C.R.; Sherwood, J. Tools and techniques for solvent selection: Green solvent selection guides. Sustain. Chem. Process 2016, 4, 7. [CrossRef]

22. Longo, L.S., Jr.; Craveiro, M.V. Deep Eutectic Solvents as unconventional media for multicomponent reactions. J. Braz. Chem. Soc. 2018, 29, 1999-2025. [CrossRef]

23. Zeisel, S.H. A brief history of choline. Ann. Nutr. Metab. 2012, 61, 254-258. [CrossRef] [PubMed]

24. Radosevic, K.; Bubalo, M.C.; Srcek, V.G.; Grgas, D.; Dragicevic, T.L.; Redovnikovic, I.R. Evaluation of toxicity and biodegradability of choline chloride based deep eutectic solvents. Ecotoxicol. Environ. Saf. 2015, 112, 46-53. [CrossRef] [PubMed]

25. Dai, Y.T.; Witkamp, G.J.; Verpoorte, R.; Choi, Y.H. Tailoring properties of natural deep eutectic solvents with water to facilitate their applications. Food Chem. 2015, 187, 14-19. [CrossRef]

26. Liu, X.; Fu, N.J.; Zhang, Q.G.; Cai, S.F.; Wang, Q.; Han, D.D.; Tang, B.K. Green tailoring with water of choline chloride deep eutectic solvents for the extraction of polyphenols from palm samples. J. Chromatogr. Sci. 2015, 57, 272-278. [CrossRef]

27. Francisco, M.; van den Bruinhorst, A.; Kroon, M.C. Low-Transition-Temperature Mixtures (LTTMs): A new generation of designer solvents. Angew. Chem. Int. Ed. 2013, 52, 3074-3085. [CrossRef]

28. Wang, H.; Liu, S.; Zhao, Y.; Wang, J.; Yu, Z. Insights into the hydrogen bond interactions in Deep Eutectic Solvents composed of choline chloride and polyols. ACS Sustain. Chem. Eng. 2019, 7, 7760-7767. [CrossRef]

29. Naseem, Z.; Shehzad, R.A.; Ihsan, A.; Iqbal, J.; Zahid, M.; Pervaiz, A.; Sarwari, G. Theoretical investigation of supramolecular hydrogen-bonded choline chloride-based deep eutectic solvents using density functional theory. Chem. Phys. Lett. 2021, 769, 138427. [CrossRef]

30. Maugeri, Z.; Domínguez deMaría, P. Novel choline chloride based deep eutectic solvents with renewable hydrogen bond donors: Levulinic acid and sugar-based polyols. RSC Adv. 2012, 2, 421-425. [CrossRef]

31. Perkins, S.L.; Painter, P.; Colina, C.M. Experimental and computational studies of choline chloride-based deep eutectic solvents. J. Chem. Eng. Data 2014, 59, 3652-3662. [CrossRef]

32. Biernacki, K.; Souza, H.K.S.; Almeida, C.M.R.; Magalhães, A.L.; Gonçalves, M.P. Physicochemical properties of choline chloridebased Deep Eutectic Solvents with polyols: An experimental and theoretical investigation. ACS Sustain. Chem. Eng. 2020, 8, 18712-18728. [CrossRef]

33. Ünlü, A.E.; Arıkaya, A.; Takaç, S. Use of deep eutectic solvents as catalyst: A mini-review. Green Process Synth. 2019, 8, 355-372. [CrossRef]

34. Sun, H.; Li, Y.; Wu, X.; Li, G. Theoretical study on the structures and properties of mixtures of urea and choline chloride. J. Mol. Model. 2013, 19, 2433-2441. [CrossRef] [PubMed]

35. Ashworth, C.R.; Matthews, R.P.; Welton, T.; Hunt, P.A. Doubly ionic hydrogen bond interactions within the choline chloride-urea deep eutectic solvent. Phys. Chem. Chem. Phys. 2016, 18, 18145-18160. [CrossRef] [PubMed]

36. Hammond, O.S.; Bowron, D.T.; Edler, K.J. Liquid structure of the choline chloride-urea deep eutectic solvent (reline) from neutron diffraction and atomistic modelling. Green Chem. 2016, 18, 2736-2744. [CrossRef]

37. Suo, L.; Borodin, O.; Sun, W.; Fan, X.; Yang, C.; Wang, F.; Gao, T.; Ma, Z.; Schroeder, M.; von Cresce, A.; et al. Advanced highvoltage aqueous lithium-ion battery enabled by “water-in-bisalt" electrolyte. Angew. Chem. Int. Ed. 2016, 55, 7136-7141. [CrossRef] [PubMed]

38. Triolo, A.; Lo Celso, F.; Brehm, M.; Di Lisio, V.; Russina, O. Liquid structure of a choline chloride-water natural deep eutectic solvent: A molecular dynamics characterization. J. Mol. Liq. 2021, 331, 115750. [CrossRef]

39. Cicci, A.; Sed, G.; Bravi, M. Potential of choline chloride--based Natural Deep Eutectic Solvents (NaDES) in the extraction of microalgal metabolites. Chem. Eng. Trans. 2017, 57, 61-66.

40. Mannu, A.; Cardano, F.; Fin, A.; Baldino, S.; Prandi, C. Choline chloride-based ternary deep band gap systems. J. Mol. Liq. 2021, 330, 115717. [CrossRef]

41. Nirwan, S.; Chahal, V.; Kakkar, R. Thiazolidinones: Synthesis, reactivity, and their biological applications. J. Heterocycl. Chem. 2019, 56, 1239-1253. [CrossRef]

42. Ashraf, S.; Saeed, A.; Moon, S.-H.; Flörke, U.; Kim, S.H.; Ashraf, Z.; Yaseen, M.; Muhammad, L. Design, synthesis and biological evaluation of 2-(naphthoyl) iminothiazolidin-4-ones as potential anticancer agents. ChemistrySelect 2020, 5, 3965-3970. [CrossRef]

43. Mobinikhaledi, A.; Amiri, A.K. Natural eutectic salts catalyzed one-pot synthesis of 5-arylidene-2-imino-4-thiazolidinones. Res. Chem. Intermed. 2013, 39, 1491-1498. [CrossRef]

44. Shiri, M.; Zolfigol, M.A.; Kruger, H.G.; Tanbakouchian, Z. Bis- and trisindolylmethanes (BIMs and TIMs). Chem. Rev. 2010 110, 2250-2293. [CrossRef] [PubMed]

45. Vanderlaag, K.; Su, Y.; Frankel, A.E.; Grage, H.; Smith, R., 3rd; Khan, S.; Safe, S. 1,1-Bis(3'-indolyl)-1-(p-substituted phenyl)methanes inhibit proliferation of estrogen receptor-negative breast cancer cells by activation of multiple pathways. Breast Cancer Res. Treat. 2008, 109, 273-283. [CrossRef]

46. Singh, A.; Kaur, G.; Bubun Banerjee, B. Recent developments on the synthesis of biologically significant bis/tris(indolyl)methanes under various reaction conditions: A review. Curr. Org. Chem. 2020, 24, 583-621. [CrossRef]

47. Grosso, C.; Brigas, A.; de los Santos, J.M.; Palacios, F.; Lemos, A.; Pinho e Melo, T.M.V.D. Natural deep eutectic solvents in the hetero-Diels-Alder approach to bis(indolyl)methanes. Bioorg. Med. Chem. 2017, 25, 1122-1131. [CrossRef]

48. Broggini, G.; Borsini, E.; Piarulli, U. Science of Synthesis, Cross Coupling and Heck-Type Reactions; Molander, G.A., Wolfe, J.P., Larhed, M., Eds.; Thieme: Stuttgart, Germany, 2013; Volume 3, pp. 521-583. 
49. Khose, V.N.; John, M.E.; Pandey, A.D.; Karnik, A.V. Chiral benzimidazoles and their applications in stereodiscrimination processes. Tetrahedron Asymmetry 2017, 28, 1233-1289. [CrossRef]

50. Ñ́guez, D.R.; Khazaeli, P.; Alonso, D.A.; Guillena, G. Deep eutectic mixtures as reaction media for the enantioselective organocatalyzed-amination of 1,3-dicarbonyl compounds. Catalysts 2018, 8, 217. [CrossRef]

51. Xu, Y.-X.; Wang, H.; Li, X.-K.; Dong, S.-N.; Liu, W.-W.; Gong, Q.; Wang, T.-D.-Y.; Tang, Y.; Zhu, J.; Li, J.; et al. Discovery of novel propargylamine-modified 4-aminoalkyl imidazole substituted pyrimidinylthiourea derivatives as multifunctional agents for the treatment of Alzheimer's disease. Eur. J. Med. Chem. 2018, 143, 33-47. [CrossRef]

52. Yogev-Falach, M.; Amit, T.; Bar-Am, O.; Youdim, M.B.H. The importance of propargylamine moiety in the anti-Parkinson drug rasagiline and its derivatives in MAPK-dependent amyloid precursor protein processing. FASEB J. 2003, 17, 2325-2327. [CrossRef]

53. Lauder, K.; Toscani, A.; Scalacci, N.; Castagnolo, D. Synthesis and reactivity of propargylamines in organic chemistry. Chem. Rev. 2017, 117, 14091-14200. [CrossRef]

54. Abtahi, B.; Tavakol, H. Choline chloride-urea deep eutectic solvent as an efficient media for the synthesis of propargylamines via organocuprate intermediate. Appl. Organomet. Chem. 2020, 34, e5895. [CrossRef]

55. Matralis, A.N.; Katselou, M.G.; Nikitakis, A.; Kourounakis, A.P. Novel benzoxazine and benzothiazine derivatives as multifunctional antihyperlipidemic agents. J. Med. Chem. 2011, 54, 5583-5591. [CrossRef] [PubMed]

56. Andrea Minigher, A.; Elena Benedetti, E.; De Giacomo, O.; Campaner, P.; Aroulmoji, V. Synthesis and characterization of novel cardanol based benzoxazines. Nat. Prod. Commun. 2009, 4, 521-528.

57. Behalo, M.S.; Bloise, E.; Mele, G.; Salomone, A.; Messa, F.; Carbone, L.; Mazzetto, S.E.; Lomonaco, D. Bio-based benzoxazines synthesized in a deep eutectic solvent: A greener approach toward vesicular nanosystems. J. Heterocycl. Chem. 2020, 57, 768-773. [CrossRef]

58. Günther, A.; Pełech, R. Bio-active pyridinium salts: A mini-review on properties and selected reactions. Mini-Rev. Org. Chem. 2019, 16, 610-616. [CrossRef]

59. Smith, M.B.; March, J. March's Advanced Organic Chemistry; Wiley: Hoboken, NJ, USA, 2001.

60. Bušić, V.; Roca, S.; Vikić-Topić, D.; Vrandečić, K.; Ćosić, J.; Molnar, M.; Gašo-Sokač, D. Eco-friendly quaternization of nicotinamide and 2-bromoacetophenones in deep eutectic solvents. Antifungal activity of the products. Environ. Chem. Lett. 2020, 18, 889-894. [CrossRef]

61. Popova, A.; Bondarenko, S.P.; Frasinyuk, M.S. Aurones: Synthesis and properties. Chem. Heterocycl. Comp. 2019, 55, 285-299. [CrossRef]

62. Hawkins, I.; Handy, S.T. Synthesis of aurones under neutral conditions using a deep eutectic solvent. Tetrahedron 2013, 69, 9200-9204. [CrossRef]

63. Dlugosz, A.; Janecka, A. Novobiocin analogs as potential anticancer agents. Mini Rev. Med. Chem. 2017, 17, 728-733. [CrossRef]

64. Zamani, P.; Khosropour, A.R. A combination of natural deep eutectic solvents and microflow technology: A sustainable innovation for the tandem synthesis of 3-aminohexahydrocoumarins. Green Chem. 2016, 18, 6450-6455. [CrossRef]

65. Conti, M. Cyclopentenone: A special moiety for anticancer drug design. Anticancer Drugs 2006, 17, 1017-1022. [CrossRef]

66. Procopio, A.; Costanzo, P.; Curini, M.; Nardi, M.; Oliverio, M.; Sindona, G. Erbium(III) chloride in ethyl lactate as a smart ecofriendly system for efficient and rapid stereoselective synthesis of trans-4,5-diaminocyclopent-2-enones. ACS Sustain. Chem. Eng. 2013, 1, 541-544. [CrossRef]

67. Di Gioia, M.L.; Nardi, M.; Costanzo, P.; De Nino, A.; Maiuolo, L.; Oliverio, M.; Procopio, A. Biorenewable Deep Eutectic Solvent for selective and scalable conversion of furfural into cyclopentenone derivatives. Molecules 2018, 23, 1891. [CrossRef]

68. Bora, D.; Kaushal, A.; Shankaraiah, N. Anticancer potential of spirocompounds in medicinal chemistry: A pentennial expedition. Eur. J. Med. Chem. 2021, 215, 113263. [CrossRef]

69. Eldehna, W.M.; EL-Naggar, D.H.; Hamed, A.R.; Ibrahim, H.S.; Ghabbour, H.A.; Abdel-Aziz, H.A. One-pot three-component synthesis of novel spirooxindoles with potential cytotoxic activity against triple-negative breast cancer MDA-MB-231 cells. J. Enzyme Inhib. Med. Chem. 2018, 33, 309-318. [CrossRef] [PubMed]

70. Zhang, W.-H.; Chen, M.-N.; Hao, Y.; Jiang, X.; Zhou, X.-L.; Zhang, Z.-H. Choline chloride and lactic acid: A natural deep eutectic solvent for onepot rapid construction of spiro[indoline-3,4'-pyrazolo[3,4-b]pyridines]. J. Mol. Liq. 2019, 278, 124-129. [CrossRef]

71. Lin, R.; Chiu, G.; Yu, Y.; Connolly, P.J.; Li, S.; Lu, Y.; Adams, M.; Fuentes-Pesquera, A.R.; Emanuel, S.L.; Greenberger, L.M. Design, synthesis, and evaluation of 3,4-disubstituted pyrazole analogues as anti-tumor CDK inhibitors. Bioorg. Med. Chem. Lett. 2007, 17, 4557-4561. [CrossRef]

72. Kalla, R.M.N.; Kim, I. Highly efficient synthesis of pyrazolylphosphonate derivatives in biocompatible deep eutectic solvent. Mol. Catal. 2019, 473, 110396. [CrossRef]

73. Singh, R.; Saini, M.R.; Bhardwaj, D.; Singh, A. An expedient synthesis of new iminothiazolidinone grafted dispiropyrrolidineoxindole/indeno hybrids via a multicomponent [3+2] cycloaddition reaction in a deep eutectic solvent. New J. Chem. 2020, 44, 7923-7931. [CrossRef]

74. del Monte, F.; Carriazo, D.; Serrano, M.C.; Gutiérrez, M.C.; Ferrer, M.L. Deep eutectic solvents in polymerizations: A greener alternative to conventional syntheses. ChemSusChem 2014, 7, 999-1009. [CrossRef] [PubMed]

75. Pradeepkumar, P.; Elgorban, A.M.; Bahkali, A.H.; Rajan, M. Natural solvent-assisted synthesis of amphiphilic co-polymeric nanomicelles for prolonged release of camptothecin delivery. New J. Chem. 2018, 42, 10366-10375. [CrossRef] 
76. Gholap, S.S. Pyrrole: An emerging scaffold for construction of valuable therapeutic agents. Eur. J. Med. Chem. 2016, 110, 13-31. [CrossRef]

77. Hu, L.; Luo, J.; Lu, D.; Tang, Q. Urea decomposition: Efficient synthesis of pyrroles using the deep eutectic solvent choline chloride/urea. Tetrahedron Lett. 2018, 59, 1698-1701. [CrossRef]

78. Jiang, R.-W.; Lau, K.-M.; Hon, P.-M.; Mak, T.; Woo, K.-S.; Fung, K.-P. Chemistry and biological activities of caffeic acid derivatives from salvia miltiorrhiza. Curr. Med. Chem. 2005, 12, 237-246. [CrossRef] [PubMed]

79. Sørensen, A.-D.M.; Durand, E.; Laguerre, M.; Bayrasy, C.; Lecomte, J.; Villeneuve, P.; Jacobsen, C. Antioxidant properties and efficacies of synthesized alkyl caffeates, ferulates, and coumarates. J. Agric. Food Chem. 2014, 62, 12553-12562. [CrossRef]

80. Wang, X.; Sun, S.; Hou, X. Synthesis of lipophilic caffeoyl alkyl ester using a novel natural deep eutectic solvent. ACS Omega 2020, 5, 11131-11137. [CrossRef] [PubMed] 